\title{
LUONNONILMIÖT TEKEVÄT KUVIA - MUTTA MITEN?
}

Tuula Närhinen: Kuvatiede ja luonnontaide. Tutkielma luonnonilmiöiden kuvallisuudesta. Taideyliopiston kuvataideakatemia 2016, kuvataiteen tohtorin tutkinnon opinnäytteen kirjallinen osa.

Taiteellisen tutkimuksen perustana on ajatus, että taiteilijat voivat harjoittaa taiteellista tutkimusta tehdessään taidetta. Miksi eivät voisi? Tieteellistä tutkimusta harjoitetaan tekemällä tiedettä. Taiteen ja tieteen historioihin sisältyy paljon kertomuksia siitä, miten virikkeet ovat välittyneet alojen rajojen yli hienoin tuloksin. Monet tieteilijät ovat esimerkiksi käyttäneet taiteen piirissä kehitettyjä menetelmiä tutkimustensa ja koejärjestelyjensä apuneuvoina. ${ }^{1}$ Vastaavasti toisin päin: tieteen ja tekniikan avulla taiteilijat ovat saaneet uudenlaisia välineitä toteuttaa teoksiaan. On siis ehdottomasti mielekästä ajatella, että systemaattinen ja pitkäjänteinen taiteellinen työ itsessään voi olla tutkimuksellista.

Tieteellinen tutkimus asettuu luonnolliseksi vertailukohdaksi. Siksi on tärkeää kyetä täsmentämään taiteellisen ja tieteellisen tutkimuksen samankaltaisuuksia ja eroja. Lähestyn kysymystä tietenkin oman tutkimuksellisen kokemukseni näkökulmasta. Tieteellisen tutkimuksen olennaisia kategorioita ovat tutkimusongelma ja tutkimustulos sekä näiden tulkintayhteydet eri tavoin artikuloituina. Alan Garfinkel pelkisti kysymyksen ja vastauksen välttämättömän rinnakkaisuuden aforistiseen kysymykseen "If social science is the answer, what is the question." Garfinkel esitti, että rinnakkaisuuden luonnetta voi selventää konstruoimalla kysymyksen taustalle vastakohta-avaruuden (contrast space), joka jäsentää vastaukseksi kelpaavien vaihtoehtojen määrittämän semanttisen tilan. ${ }^{3}$

Garfinkelin aforismia muuntaen voimme kysyä: Jos taiteellinen tutkimus tarjoaa vastauksen, mikä on kysymys? Tuula Närhisen tohtorin tutkinnon opinnäyte Kuvatiede ja luonnontaide. Tutkielma luonnonilmioiden kuvallisuudesta on tarjonnut minulle tähän aihepiiriin opinto-ohjausta. Närhisen kuvataiteen tohtorin opinnäytetyöhön sisältyy vakiintuneen normin mukaisesti sekä taiteellisia produktioita - neljä näyttelyä - että niihin perustuva tekstiosuus. Näyttelyt (Liplatus; Merivesivärit; Sateen kosketus; Muovimuotoilua Itämerestä) ajoittuivat vuosille 2009-2014; niiden yhteinen teema oli vesi. Närhinen esittelee työnsä kirjallisessa osassa jokaisen niistä omassa luvussaan. Tutkielman ennakkotarkastajat olivat nähneet jokaisen näyttelyn, ja niistä sisältyi arvio heidän esitarkastuslausuntoonsa. Olin itse nähnyt ennalta muutamia produktioiden osia, mutta näkemykseni kokonaisuudesta perustui Närhisen laatimiin kuvauksiin sekä hänen kotisivujensa laajaan materiaaliin. ${ }^{4}$

Närhinen jakaa tutkielmansa tekstiosuuden kahteen osaan. Ensimmäisessä osassa, Luonnontaide, hän esittelee opinnäytteeseen sisältyvät näyttelyprojektit. Osan kokoavaksi teemaksi hän nimeää tutkielmansa johdannossa (s. 9): "tapaustutkimuksia veden kuvallisesta potentiaalista". Jälkimmäisen osan, Kuvatiede, neljässä luvussa Närhinen käy läpi teoreettisia teemoja, jotka selventävät sekä yksittäisten näyttelyprojektien että koko tutkielman tavoitteita. Näissä luvuissa hän käyttää argumenttiensa tukena myös useita aiempia projektejaan (Eläinkamerat 2002; Tuulipiirturit 2000; Surf 2001; Eläinten jäljillä 2004)5. Osan tavoitteeksi Närhinen mainitsee, että se 
"lähestyy luonnon kuvaamista tietoa tuottavana metodina".

Tutkielma on kunnioitettavan laaja-alainen kokonaisuus. Närhinen toteaa johdannossa pitäneensä työnsä mallina episodielokuvaa; hän kirjoittaa (s. 11): "Sovellan episodielokuvalle tyypillistä vaihtuvien näkökulmien dramaturgiaa: nostan kuvallisen välitystyön osatekijöitä vuorotellen tarkastelun kohteeksi."Tutkielman episodisuus ilmenee siten, että Närhinen ei kerro etukäteen, mitä hän tutkielmansa varsinaisissa sisällöllisissä luvuissa käsittelee, vaan aiheet tulevat esiin vuorollaan silloin kun esityksen logiikka sitä vaatii. Tutkielma ei pyri jäljittelemään deduktiivisesti etenevää argumenttia, vaan se rakentuu kuin kudelma, jonka osat ja kokonaisuus puhelevat keskenään.

Närhinen kuvaa oman tutkimuksensa tavoitteet työnsä johdannossa seuraavasti (s. 9):

Miltä näyttävät aallon, sateen tai meriveden kuvat? Millaisin keinoin luonto piirtyy kuvallisiksi esityksiksi? Luonnonilmiöt toimivat teoksissani kuvantekijöinä. Samalla paljastuu, miten kuvat esittävät kohteitaan. Työni toimivat eräänlaisina välittävinä rajapintoina tai kulttuurisina käyttöliittyminä. Esitän kuvaamiseen tarvittavan laitteiston yhdessä työn tuloksena syntyneen kuvamateriaalin kanssa. Teokseni re-presentoivat luonnonilmiöitä: ne pyrkivät luomaan ilmiön uudelleen visuaalisena kokemuksena.

Närhisen taiteellisen tutkimuksen taustalla on tiettyjen luonnonilmiöiden kuten tuulen ja sateen luomien (tai niitä "uudelleen-esittävien") kuvien sekä kuvien tieteellisen käytön välinen jännite. Luonnonilmiöt eivät tee kuvia itsestään. Närhisen projektien olennainen yhteinen piirre on ollut siinä, että sekä luonnonilmiöt että taiteilija itse ovat olleet kuvia tuottavissa prosesseissa toimijoita, "agentteja". Erilaisten toimijuuksien suhteita välittävät Närhisen kehittämät kekseliäät "tee-se-itse" -laitteet, joita hän on käyttänyt projekteissaan, esimerkiksi aaltokiikari ja aaltopiirturi näyttelyssä Liplatus $^{6}$.

Projektien moninaisuus ilmentää osaltaan Närhisen taiteellisen tutkimuksen episodista lähestymistapaa. Hän on suunnitellut eri projektinsa siten, että niistä jokaisesta syntyy positiivinen resonanssi samaan ilmiöön kohdistuvan tieteellisen tutkimuksen kanssa. Tutkielmansa tekstissä Närhinen hahmottelee projektiensa yhteyksiä erityisesti sellaiseen luonnontieteelliseen tutkimukseen, joka on tukeutunut kuviin ja käyttänyt hyväkseen kuvallista aineistoa. Tärkeitä rinnastuksia luonnontutkimuksen historiasta Närhiselle tarjoavat etenkin Ernst Haeckel, Antoni van Leeuwenhoek sekä Étienne-Jules Marey kaikki tunnettuja kuvien tekijöitä ja käyttäjiä. Hän esittelee seikkaperäisesti jokaisen näistä ja luo jännittävät rinnastukset omiin teoksiinsa nähden. Tämä vaatii melkoista rohkeutta, sillä esikuvat ovat laajalti tunnettuja ja heidän työnsä on kuvattu rikkaassa lähdekirjallisuudessa; Närhinen esittelee myös sekundaarikirjallisuuden hyvin.

Näiden kolmen tutkijan työt rinnastuvat itse asiassa Närhisen episodiseen lähestymistapaan: he selvittivät ilmiöitä, joiden luonteesta ei vielä heidän omana aikanaan ollut vakiintunutta käsitystä, saati että heidän tutkimuksillaan olisi ollut vakiintuneiden teorioiden tuki. Antoni van Leeuwenhoek (1632-1723) kehitti mikroskoopin prototyyppejä ja kuvasi niiden avulla aiemmin näkymättömiä pieneliöitä; harvat aikalaiset uskoivat edes todeksi sen, mitä Leeuwenhoek havaitsi. Étienne-Jules Marey (1830-1904) loi uutta teknistä välineistöä käyttäen täsmällisiä pysäytyskuvia liikkuvista olioista ja objekteista. Ernst Haeckel (1834-1919) seikkaili darwinistisen vallankumouksen innoittamana pieneliöiden kummallisten anatomisten ja morfologisten muotojen tuolloin vielä tuntemattomalla maaperällä.

Taiteellisen työn rinnastuskohtia Närhiselle tarjoavat suomalaisittain Lauri Anttila, Eija-Liisa Ahtila ja Jyrki Siukonen. Kansainvälisiksi vertailukohteiksi hän nostaa muiden 
muassa Hans Haacken, David Hockneyn ja Olafur Eliassonin.

Olennaisia käsitteellisiä kysymyksiä nousee Närhisen pohdintaan pitkin matkaa. Episodielokuvan ideaa vastaten ne ovat läheisesti yhteydessä kunkin jakson varsinaiseen sisältöön. Närhinen esittää myös varsin selviä omia kantoja käsittelemiinsä kysymyksiin, mutta ne ovat mielenkiintoisella tavalla lähestulkoon piilossa sivuhuomatuksina tai alaviitteisiin sijoitettuina ikään kuin lisähuomioina. Ymmärrän tämän tietynlaisen arkuuden sitä vasten, mitä Närhinen kirjoittaa tutkielmansa johdannossa (s. 16-17):

Itseäni ovat monessa vaiheessa vaivanneet taiteellisen tutkimuksen metodeja ja mielekkyyttä koskevat epäilykset. ... [E]ntä jos kaiken päätteeksi huomaa, että kuvalliset teokset sittenkin puhuisivat omasta puolestaan paremmin kuin niitä sanallistamaan pyrkivä taiteilija-tutkija? Tuloksistakaan ei ole varmuutta.

Närhinen tavoittaa tässä ehkä yhden olennaisen taiteellisen tutkimuksen luonteeseen kuuluvan tekijän. Taideteokset ovat ainutkertaisia, kun sen sijaan olennainen tieteellisten tutkimustulosten piirre on toistettavuus; toistettavuuden merkityksestä vaativalle laboratoriotutkimukselle on käyty keskustelua esimerkiksi tiedelehti Naturen pääkirjoituksia myöten. ${ }^{7}$ Taideteoksiin sovellettuna vaatimus täsmällisestä toistettavuudesta sen sijaan olisi hyvin outo. Närhinen esittää tähän liittyvän oivalluksensa kirjoittamalla (s. 265), että "[t]ulkintakontekstin vaihdos luonnontieteestä taiteeksi näyttää vaikuttavan kuvien sisältöön. Taiteen piirissä luonnonelementit helposti ikään kuin sielullistuvat ja kohoavat itsenäisiksi toimijoiksi: puut piirtävät ja meri kirjoittaa."

Kun konteksti muuttuu tieteellisestä taiteelliseksi, periaatteessa täsmälleen samanlaisena pysyvän kuvan kantamat konnotaatiot muuttuvat. Tulosten tulkitseminen on molemmissa tapauksissa yhtä tärkeää, tulkinnan kontekstit eroavat.
Tieteellisessä kontekstissa tulosten merkitykseen liittyy olennaisesti tulosten yleistettävyys. Taiteellisessa kontekstissa olennainen ulottuvuus sisältää ainutkertaisuuden elementin, ja siksi - uskoisin - yleistettävyyden tavoite liittyy pikemminkin lähestymistapaan ja menetelmiin kuin työn tuloksena syntyvään teokseen. "Tee-se-itse" -laitteistot, jotka Närhinen on kehittänyt projektiensa osana, ovat erittäin tärkeä osa sekä valmistuneita teoksia - näyttelyitä ja niiden sanallista esittelyä - että hänen taiteellista tutkimustaan.

Isabelle Stengers on pohtinut eron luonnetta rinnastamalla toisiinsa Beethovenin ja Newtonin: jos Beethoven olisi kuollut synnytyksessä, hänen sinfonioitaan ei olisi olemassa; sen sijaan jos Newton olisi menehtynyt teini-ikäisenä, hänen nimeään kantavat dynamiikan lait olisi kehittänyt joku toinen; tai näin voimme uskoa. ${ }^{8}$ Ero johtuu siitä, että Newtonin dynamiikka on vastaus ongelmaan, jonka inhimilliset yhteiskunnat voivat kohdata samankaltaisena kaikkialla ja kaikkina aikoina ja jolle on olemassa sangen yksikäsitteinen vastaus. Beethovenin sinfonioiden taustana ei ole samankaltaista selvärajaista ongelmaa. Tämä rinnastus selkiyttää myös vastakohtaavaruuksien erilaista asemaa taiteellisessa ja tieteellisessä tutkimuksessa.

Närhisen työt keskustelevat erityisesti luonnontutkimuksen kanssa. Taiteellinen tutkimus tuskin tuottaa luonnontieteen tulosten kaltaista uutta, käsitteellisesti kiteytettyä tietoa luonnon ilmiöistä. Laajemmassa mielessä Närhisen tekemä työ kuitenkin laajentaa luontoa koskevaa tietämystä. Hyvä termi kuvaamaan taiteellisen ja tieteellisen tutkimuksen tulosten yhtymäkohtia voisi olla kognitiivinen herkkyys: sekä taide että tiede parantavat kykyämme havainnoida ja todentaa ympäristössä tapahtuvien ilmiöiden olennaisia piirteitä. Nimenomaan tässä mielessä esimerkiksi aaltokiikarin tuottamat kuvat tai vesipiirturin tuottama kirjoitusjälki tarjoavat uudenlaisen ja omalla tavallaan yleistettävän näkemyksen veden käyttäytymisestä ympäristömme tärkeänä elementtinä. 
Vastaava päätelmä soveltuu mutatis mutandis yhteiskunnallisesti ja kulttuurisesti herkistyneen taiteellisen tutkimuksen vaikutukseen.

Voidaanko aineisto ja analyysi erottaa toisistaan kuten tieteellisessä tutkimuksessa? Millaisista alkeisosista (havainnoista) aineisto muodostuu? Ovatko havaintoyksikkö ja analyysin yksikkö erotettavissa toisistaan? Taiteellisessa tutkimuksessa aineiston ja analyysin suhde on monitasoinen ja vivahteikas. Ehkä analyysin yksikköä vastaa lopullinen työ, ja havaintoyksikköjä ovat ne ainekset ja työvaiheet, joiden tuloksena se on syntynyt. Olennainen ero tieteellisen tutkimuksen käsitteistöön on siinä, että tekeminen itsessään on niin olennainen osa taiteellista tutkimusta.

Myös tieteellisessä tutkimuksessa "tee-seitse" -laitteilla on toki tärkeä asema edelleen. Pelkistetyt havainto- tai koejärjestelmät täytyy tutkijoiden itse luoda, niitä ei ole luonnossa valmiina. Toistettavuuden vaatimus kuitenkin vähentää tutkijoiden vapausasteita: havainnoinnin ja kokeiden protokollat on $\mathrm{ku}^{-}$ vattava selkeästi ja yksikäsitteisesti. Arvelisin, että Tuula Närhisellä on ollut enemmän mahdollisuuksia tehdä villejä kokeiluja. Tavallaan hänen tuottamansa teokset ovat itsessään "malleja" niistä ilmiöistä, joiden havaitsemista hänen teoksensa auttavat; kuten hän kirjoittaa epilogissa (s. 357): "Luonnehdin taideteosta katselulaitteeksi, jonka puitteissa taiteilija asettaa haluamansa näkökulman.”

Yksittäisten mallien todistusvoima syntyy siitä, että niiden ainekset tunnetaan. Näkökulmien moninaistuessa asetelma lähenee ihannetta, jonka teoreettisten mallien kehittämistä paljon pohtinut populaatiobiologi Richard Levins kiteytti aformiksi: "Our truth is the intersection of independent lies" ${ }^{9}$ - eli meidän totuutemme muodostuu siitä, miten lukuisat eri tavoin pelkistetyt ja "valheelliset" mallit johtavat samoihin päätelmiin.

Närhinen on kehittänyt uudenlaisia tapoja tuoda ilmi luonnon tapahtumakulkujen moninaisuutta ja rikkautta. Hän kykenee myös artikuloimaan omien töidensä yhteyden aiempaan luonnontieteelliseen tutkimukseen. Ambivalenssin - kahtalaisuuden, monitulkintaisuuden - esittäminen on tässä yksi avainkysymyksistä. Ambivalenssit auttavat oivaltamaan ilmiöiden ja tulkintojen moninaisuutta. Ambivalenssit ovat sukua dualismeille, joista ei kokonaan voi päästä eroon mutta jotka voidaan ymmärtää tutkimuksen teon käsitteellisiksi apuneuvoiksi. Tutkielmansa johdannossa (s. 16) Närhinen viittaa Gaston Bachelardin ajatukseen, että järjen ja runouden välinen jännite on ajattelun dynaaminen käyttövoima. Tämän dualismin määrittämä jännite kulkee läpi koko työn ja tulee valotetuksi useista suunnista eri yhteyksissä.

Ambivalenssi koskee jopa perustavia kysymyksiä kuten havaintojen tekoa, eli kysymystä: Voinko havaita ilmiön, josta en tiedä, mikä se on? Närhinen esittää tästä henkilökohtaisena kokemuksenaan vaikeutensa huomata niin sanotut merenneidon kyyneleet eli mereen joutuneen muovin murskautumisen tuottamat helmimäiset muruset Harakan saaren rannassa (s. 127-8). Vaativammassa mielessä havainnoinnin ambivalenssin tuovat esiin tutkimusvälineiden avulla tuotetut kuvat: On tiedettävä, miten kuva on otettu, jotta voisi ymmärtää sen sisällön. Mutta mitä kehittyneempi välineistö on, sitä suuremmaksi tulee illuusion riski. Tätä asetelmaa Närhinen esittelee muun muassa van Leeuwenhoekin mikroskooppikuvien sekä Étienne-Jules Mareyn valokuvatutkielmien avulla käyttäen rinnastuksina omia teoksiaan.

Tärkeä taiteellisen ja tieteellisen tutkimuksen eroja ja yhtäläisyyksiä luotaava kysymys koskee niiden eettisten normien luonnetta, joita työ ilmentää. Täysin normeista irrallista tutkimusta ei ole. Tieteellisessä tutkimuksessa normit tulevat ensisijaisesti ilmi kysymyksenasettelussa, joka kiinnittää tulkinnan kehyksen. Taiteellisessa tutkimuksessa ei ole samalla tavoin tarkoin määriteltyjä tutkimuskysymyksiä. Kuten Närhinen kuvaa omaa tutkimuksellista otettaan (johdanto, s. 17): "Omassa taiteessani tutkiva ote näyttäytyy leikittelynä ja päättömiltä vaikuttavina, mutta vakavasti otettavina kokeiluina."Tämänkaltaisen taiteellisen tutki- 
muksen normatiivisuus tulee ilmi sen kautta, millaista kontekstia taideteosten tulkitseminen edellyttää.

Tässä suhteessa Närhisen näyttelyt $1 \&$ 3 ja toisaalta $2 \& 4$ muodostavat toisistaan poikkeavat parit. Edellinen pari tutkii sitä, millaisia kuvia veden tietyt ilmenemismuodot (aallokko, sade) tuottavat. Jälkimmäisessä parissa pääosassa ovat ihmistoimien aiheuttamat veden laadun muutokset: veteen liuenneet yhdisteet (näyttely 2) ja Itämeren muovisaaste (näyttely 4). Jälkimmäisen parin näyttelyiden teoksissa ei kuitenkaan ole mitenkään hallitsevana ympäristön pilaantumisen vastainen eetos, kuten voisi odottaa. Sen sijaan teosten eettistä latausta luonnehtii ambivalenssi: Vettä haihduttamalla aikaansaatu "keitto" voi olla ulkoasultaan mielenkiintoinen (näyttely 2), ja Itämeren kantamasta muovirojusta voi muotoilla mielenkiintoisia hahmoja (näyttely 4). Ambivalenssi kiteytyy siihen, että molempien näyttelyiden teoksissa salaperäisen kiehtova ulkoasu ja perustavasti vastenmielinen olemus kietoutuvat toisiinsa.

Närhisen tutkielmaa läpäisevät eettiset kysymyksenasettelut tulevat ilmi vaihtelevissa muodoissa. Kuvaamisen luonne nousee esiin Itämeren muovista valmistettujen olioiden kohdalla (s. 168): "Muovi-ilmiössä meriekosysteemit edustavat sekä taiteellisen luovuuden alkulähdettä että uutta synnyttävien prosessien kaatopaikkaa - sitä aineellista ja psyykkistä "tiedostamatonta", jonka jäljet pulpahtelevat pintaan räjähdyksenomaisina ja yllättävinä purkauksina.”

\section{VIITTEET}

1. Galileo Galilei kykeni taitavana muusikkona tavoittamaan korvaansa metronomin rytmin ja arvioimaan tällä keinoin etäisyydet, jotka kaltevalla pinnalla pyörivä metallilieriö saavutti vakioitua aikayksikköä kohden sen nopeuden kiihtyessä; ks. George Pólya, Mathematical Methods in Science (The Mathematical Association of America, 1977).
Pyrkimys hallita on yksi kuvaamiseen liittyvistä ongelmista: kuvaaja hallitsee aina tilanteen suhteessa kuvattavaan. Kuka antaa tähän oikeuden? Bruno Latouriin viitaten Närhinen toteaa (s. 321), että "tiettyyn paikalliseen kontekstiin sidottua empiiristä todellisuutta ei voi koskaan jäännöksettömästi muuntaa kuvalliskirjallisiksi esityksiksi”. Hallitsemisesta voi pyrkiä irtaantumaan tavoittelemalla kumppanuutta, joka on myös aina kuvaamisessa latenttina läsnä. Antoni van Leeuwenhoekista Närhinen toteaa (s. 231), että tämä "ryhtyi rohkeasti löytämiensä pikku eläinten puolestapuhujaksi haastaen samalla koko aristoteelisen tutkimusperinteen sekä sen levittämän opin itsestään sikiämisestä”. Samaan tavoitteeseen Närhinen kytkee oman teoksensa Eläinten jäljillä [2004], (s.319);"[V]oin todeta, että eläinten jäljet koskettavat ja liikuttavat minua.... Oli välillämme sitten tassunjälki tai suora katsekontakti - halusimme tai emme, jälkien välityksellä tapahtuvat kohtaamiset asettavat meidät silmätysten oman eläimellisyytemme kanssa.”

Taiteellisessa tutkimuksessa henkilökohtaisen kokemuksen paino on suhteellisesti paljon suurempi kuin tieteellisessä tutkimuksessa. Objektiivisuuden ja subjektiivisuuden dualismi on kelvoton käsitteistö tämän kuvaamiseksi. Hetken kunnioittaminen, herkkyys tilanteelle ja sen erityisille piirteille, sekä tutkija tilanteisiin osallistuvana subjektina, kanssaeläjänä, ovat olennaisia määreitä. Kuten Tuula Närhinen toteaa (s. 57):"Ihmisen osa on olla osallinen."

$$
\text { - YRJÖ HAILA }
$$

2. Epigrammi teoksessa Alan Garfinkel, Forms of Explanation. Rethinking the Questions in Social Theory (Yale University Press, 1981).

3. Vastakohta-avaruuksista ks. myös Chuck Dyke, The Evolutionary Dynamics of Complex Systems. A Study in Biosocial Complexity (Oxford University Press, 1988); Yrjö Haila, Retkeilyn rikkaus. Luonto ympäristöbuolen 
aikakaudella (Taide, 2004).

4. Ks. http://www.tuulanarhinen.net/artworks/ - opinnäytteeseen sisältyvät projektit: Clapotis, Seawatercolours, Touch of Rain sekä Baltic Sea Plastique. Toimin tutkielman tarkastajana eli vastaväittäjänä.

5. Kotisivulla projektit: Animalcams, Windtracers, Surf sekä Tracing animals.

6. Ks. http://www.tuulanarhinen.net/artworks/clapotis. html: Wavescreen ja Wavetracer.
7. Pääkirjoitus "Go forth and replicate!", Nature $25 \mathrm{Au}-$ gust 2016 (vol. 536, s. 373).

8. Isabelle Stengers, The Invention of Modern Science (University of Minnesota Press, 2000); Stengers kyllä problematisoi taitavasti tämän itsestään selvältä vaikuttavan eron.

9. Richard Levins, "The strategy of model building in population biology", American Scientist 54, 421-431; lainaus s. 423 (1966). 